\title{
Spain is Different Mass Tourism and Gender Idendities in the Sixties
}

\author{
Aintzane Rincón \\ UPV/EHU, Basque Country, Spain
}

\begin{abstract}
In Spain, the historical context of the sixties was experienced as a particularly changing one. Gone were the post-war years, and with them the autarchy, poverty and famine, characteristics of that time. After a transitory fifties decade, the country entered a prosperous time, which is known as the develompentism sixties-desarrollismo. The franscoism itself promoted this change. Meanwhile, it became a mandatory to guide the population so the fostered modern life did not imply, among other issues, an abandonment of the traditional gender order. Popular cinema played a key role in that objective. Particularly tourism narratives had direct implications on the renewed way to understand gender identities. In this article we will approach two blockbusters, as representative examples of the mainstream films productions, through which analyse how masculinity and femininity were screened and considered.
\end{abstract}

Keywords: mass tourism, popular cinema, gender identities, sexuality

In the sixties, the idea of developmental change permeated the whole of Spanish society, and so it was experienced as a particularly changing time. The new economic and political direction adopted by the regime at the end of the forties, helped to that perception (Molinero \& Ysàs, 2008; Biescas \& Tuñon de Lara, 1990). Furthermore, the dictatorship had been able to project an idea of social and economic transformation that brought the country nearer to the capitalist Western world. Indeed, the Spanish social, economic and also political context of the sixties was considerably different to that of the post-war period. Changes associated with gender identities were also significant, and the social order of the post-war years, characterized by a selective conservative nationalism and double standards in the sexual arena, gradually started being altered and influenced by new values (Morcillo, 2008, 2010). The evolution of gender relations walked hand in hand with a renewed dictatorship discourse, closely connected to the capitalist development rhetoric. The capitalist societies' way of life - social mobility, urban, mass consumption —was, now, a part of the experience of a growing number of Spaniards, or at least, it was among their near future goals. Far from being fully criminalized, as it was in previous years, this standard of living was sponsored by the regime itself as a legitimate life aspiration. This evolution of the Franco dictatorship did not betray the ultra-conservative and totalitarian vision that

\footnotetext{
* This work had been done within the framework of the University of the Basque Country's research group titled "La experiencia de la sociedad moderna en España, 1870-1990" (GIU11/22, UFI 11/27 and MINECO code: HAR2012-37959-C02-01) - supported by the UPV/EHU and the Ministry of Economics and Competitiveness.

Aintzane Rincón, Ph.D. University of the Basque Country. Her research focuses on the analysis of female and male identity models during the Franco period and the Spanish political transition. Her thesis won the Research Prize Cátedra Juana de Vega (2012) from the Universidad de Santiago de Compostela and the V Research Prize Miguel Artola (2012) from the Asociación de Historia Contemporánea and was published in 2014: Spanish Cinema and Gender Representations (1939-1982): figures and fissures (Representaciones de género en el cine español (1939-1982): Figuras y fisuras, CEPC, USC, Madrid, 2014).
} 
characterized it since it's beginning (Molinero \& Ysás, 1999, pp. 129-242). In fact, it became an imperative to guide the citizenship in an orderly transition to this new lifestyle, so that the change did not mean the abandonment of the traditional morality and that would not affect the established gender order. The popular cinema production, and especially tourism films, played a key role in this issue ${ }^{1}$. Strongly controlled by the government through a strict censorship politic (Gubern, 1981), cinema narratives messages converged with the dictatorship aspirations of maintaining the gender order. Thanks to the appellative power they possess, film productions became one of the most effective devices to define the acceptable masculinity and femininity in this period.

\section{Theoretical Framework}

This study is based on the idea that the tourist logic that reproduced the popular cinema of the sixties was able to impose a particular way of understanding gender identities. So the research approaches the normative discourses present in movies, considering them not as linguistic expressions of society but as mediations that structures the identities and human action. That way, the methodological and conceptual fundaments that have guided the elaboration of this article are based on the works that give a central role to language in the historical analysis, assuming the theoretical principles of the linguistic turn and the latest contributions offered to it by the "incorporation paradigm" (Bonnel \& Hunt, 1996; Díaz Freire, 2003, pp. 62-70; 2007, pp. 5-29). From that point, we consider the subjectivity/identity as a process, as a constantly changing unstable discursive construction. Even if identity is usually taken as given, solid and unchangeable, we consider it as an illusion, as a representation or a category that helps people to order their world. Since nothing in humans, even their bodies, is stable, the historical approach of their building process is more than pertinent ${ }^{2}$. How were understood male and female identities at a certain historical moment? This is, in fact, the main goal of this article: We will show how tourism discourse of the sixties Spain worked on subjectivities producing a particular way to comprehend the gender identities.

The cinema sources provide us with particularly rich information to our purposes. Cinema productions are actively involved in the process of the construction of gender identities (Labanyi, 2010, pp. 223-233). The cinema stories have played - and still do - a key role in the naturalization of the sexual difference discourse. As narrative structures that often reproduced-while also constructs - the gender conventions through repetition, films are key devices in the production of gender expectations among the public, and so crucial in the legitimation of the normative discourses ${ }^{3}$. According to that, our research does not seek to find in the movies a true reflection of the society in which the films were created. This study considers culture as a space in which different agents struggle to establish their presence and their ways of understanding the world (Bennett, 1986, p.

\footnotetext{
1 The promotion and development of the tourism industry began to take shape as a response to specific political problems, such as the improvement in payments balance or the repair of international diplomatic relations. It was also responsible of the economic boom of the sixties. But, what we think is more remarkable is related to the great symbolic power the tourism imaginary had to project and construct a new social reality (Crumbaugh, 2007, pp. 151-163; 2009, pp. 15-39).

${ }^{2}$ Even in contexts of profound transformations, gender identities/ideals have often shown a strong resistance to changes. History proves to be, in this field, an essential epistemological tool to unmask the mutable and contingent nature of gender roles, and particularly useful for the abandonment of a conception of bodies as possessing unchangeable essences (Aresti, 2010, p. 13).

3 The performance of gender is based on the ritualized iteration which also produces legitimation. The American philosopher Judith Butler identified this phenomenon as the effect of metalepsis, that is to understand the effect as what, actually, the causes are. So it refers to the ability/capacity of the sexual differences discourses to generate the illusion that makes us think that gender categories precedes the linguistic operation that creates them. According to this idea discourses don't describe but they constructed the subject (Butler, 1999, p. 178).
} 
xiii). So our goal will be to analyze to how the socially accepted convections were played on movies and what were those representations aiming to construct.

As long as our research is focused on a particular historical context, among with reference works about how bodies and sexualized identities are constructed (Buthler, 1993, 1999, 2004; Foucault, 1977, 2002), the previous analysis about masculinity and femininity in the Francoist context has been essential sources (Vázquez \& Cleminson, 2012; Morcillo, 2008, 2010; Faulkner, 2006). We will centre our attention to the sixties context and especially to the tourism film narrative, which is here considered as a modern governance mechanism, helping the statecraft of the dictatorship - also regarding to normative gender identities (Afinogenova \& Martí-Olivella, 2008; Crumbaugh, 2002, pp. 261-276, 2007, pp. 157-158, 2009, pp. 15-39; Martín, 2007a, pp. 269-292, 2007b, pp. 179-207). As it was able to create new ways of thinking, acting, and choosing, while minimizing and hiding — sometimes awkwardly— the punitive and repressive state practices, tourism logic became to be very useful for the francoism in its reworked way of exercising power ${ }^{4}$. This statement applies also to the government of bodies, to defining the normative or acceptable masculinity and femininity. In fact, we consider that the sixties mass tourism phenomenon created a renewed conception of natives and foreign. Thus, the analysis of the popular tourist movies will help us to understand the meanings of what was considered as the acceptable femininity and masculinity.

\section{Spain Is Different, Paradisiacal, and Hospitable: Sixties Mass Tourism}

Tourism was a key industry to achieve the economic development. From the configuration of Ministry of Information and Tourism (MIT) in 1951, the State became the main tourist promoter. The sector acquired the status of a national industry, corresponding to the guidelines of the Marshall Plan and responding to the emergence of mass tourism in the years after the Word War II (Pack, 2009, pp. 137-166; Velasco, 2004, pp. 61-62). Thanks to the increase on salaries and extension of the paid vacations, more and more Spanish were able to enjoy their holiday time in coastal localities (Biescas \& Tuñón de Lara, 1990, pp. 337; Longhurst, 2000, pp. 17-28). Those places were also meeting points to other countries vacationers so natives had the opportunity to contact new cultures and behaviours.It happened especially during the administration of Manuel Fraga Iribarne (1962-1969) in the MIT, when the tourism became a social phenomenon. The promotion campaign launched in 1964 under the Spain is different slogan, achieved great popularity and stuck in the popular imagination (Pack, 2009, pp. 167-209). That tourism promotion legend alluded to the national difference, the uniqueness of the country. This idea seems discordant with the context in which the regime strove to present itself as no stranger to the Western democracies in order to gain the international communities approval. An approach to the market economy logic, particularly in what concerns to the mass tourism industry, offers some possible answers to this apparent paradox.

As modern societies consumers look to choose from a variety of unique and unrepeatable products, so they do when deciding their holiday destination. The modern holidaymaker, wrapped in a certain sense of losing of authenticity in her/his everyday life, tend to seek contact with something different to her/his ordinary living. The modern tourist is defined by a search of an experience that could carry him/her close to something authentic, which is perceived as belonging to an archaic and distant past, located in a primitive, underdeveloped or exotic destination (Cannel, 1976, pp. 11-13; Bonami, 2005, p. 96). The success achieved by the dictatorship

\footnotetext{
${ }^{4}$ In this article, the idea of power is considered as a decentralized and fragmented exercise that collaborates in the construction of identities (Foucault, 1977, pp. 112-117).
} 
marketing the Spanish uniqueness lay, precisely, in the ability to capitalize the staging of difference (Kirshenblatt-Gimblett, 1998, p. 74). The francoism tourism logic appeared as a perfect channel for the exaltation of a re-elaborated national uniqueness. The sixties Spain offered to the developed Western world a paradise of sun and beaches, authentic and genuine, a place where visitors could contact with remote elements of a national character. In a way, identity and heritage offered to tourism were configured according to what, supposedly, the tourism consumers aimed to find when visiting Spain. According to the government, it was the traditions - a certain kind of understanding them — what made Spain to be the internationally tourism attraction it was. The constant influx of visitors appeared as an obvious fact of it. Proposing the constant arrival of visitors as a proof of the appeal the Spanish traditional values produced around the world, the dictatorship managed to take a great political advantage of the tourism industry. The following words of Manuel Fraga Iribarne, the responsible of the MIT, were explicit at this point:

Tourism confirms the validity and fruitfulness of [our] values. Hence tourism, making our people and country to be known is tremendously helpful to the claim of the Spanish personality. In the end it helps to prove the effectiveness of a political system that had maintained it's order for over twenty-seven years and pushes our-until yesterday — underdeveloped country to new economic horizons. (Fraga Iribarne, 1965, p. 93)

It was not that the only message that the Spain is different slogan held. Inwardly, it also alluded to the huge contrast of the prosperous present the country was living with it's past. Closely linked to developmental narrative logic, the slogan reference to difference can be read as that of the overcome-yet praised - dark past. The idea according to which the economic backwardness and the anachronism image of the country within the international context, typical of the post-war period, was something regarding to the past seemed unquestionable. Spain appeared, inward and outward, with a new skin (Pavlovic, 2004, pp. 213-226; 2011). At the same time, fidelity to the regime principles and the effective leadership of Franco were presented as main responsible for the prosperous and developed present. Thanks to the dictator and his knowledge to govern the country, the misery and darkness of post-war years were gone without losing the authenticity and the essence of the country. As long as it was what foreign vacationers were looking for when visiting Spain, the dictatorship ability to know how to maintain the inner character in the modern times was presented as key to the success. So, indirectly, tourism worked as an effective propaganda through the good work of the government and its lead manager. As Manuel Fraga Iribarne recognized: "tourists are one of our best means of propaganda" (ESPAÑA (MIT)., 1953, p. 11) $)^{5}$.

The popular writer Manuel Vazquez Montalban made an ironic reading regarding to tourism logic and the Spanish character. Thus he stated that "when the Cordobés, the bullfighter in the sixties, displays the cape, it does so basically for foreigners. They ask, we give" (Vázquez Montalbán, 1998, p. 193). In other words, natives would act accordingly to what the dictatorship claimed that the tourist expectations were. The popular cinema of the sixties presents multiple episodes suggesting that same idea. One of those numerous scenes was offered by the film Un rayo de luz (Lucía, 1960) when a Spanish girl was asked by her grandfather to perform some typical dance of her homeland. Dressed in a traditional costume she sang and danced while her English governess exclaimed, “Oh! Typical Spanish!” (Lucía, 1960, 1:07:20-1:11:00). This type of representation was

\footnotetext{
5 According to this equation, the future was predicted promising, provided that the country continued to be guided by the principles that had given this positive present. That way, it could be also add that the tourism logic helped as a new legitimization source of the dictatorship (Cenarro, 1998, pp. 6-7).
} 
part of the capitalist reification of the national idiosyncrasy, now serving international citizens leisure and desire purposes. The way of acting accordingly to what the other expects became a way of being. Although, temporarily, this rhetoric was a useful device for the francoism nationalistic goal, it implied a deep contradiction with one of the dictatorship ideological basis, as it was the idea of considering the national identity as innate. In fact, opening identity to the commercial circuit as a marketable product, it turned out to be modifiable. So, even if the tourism industry provided native being presented as typically Spanish, some way, the regime accepted the acting aspect of it.

\section{The Cinematic Representation of the Foreign}

The constant visit of tourists and, consequently, the increasing contact of Spaniards with visitors from other countries, contributed to an amendment on the perception of the foreign. As it happened in previous years, people from abroad remained being depicted, mainly, as a source and origin of corruption, betrayal, perversion, liberalism, and, above all, lack of moral principles. However, immersed in the context of economical development discourse, western countries visitors, including their habits and lifestyle, became an object of desire and admiration for Spanish citizenship. Thus, an ambivalent attitude of a visceral rejection together with admiration towards the foreign was consolidating during the sixties (Barbadillo, 1997, p. 158). This contradictory feeling of devotion and animosity toward the foreign was screened in an episode of the successful film Búsqueme a esa chica (Palacios \& Sherman, 1964). The film told the story of Marisol and her father, a couple trying to survive on vacationers alms in exchange for their street performances. The symbolically significant film passage we want to focus on is that one which went on a bullfight in honour of two American visitors: the magnate Mister Morrison and his secretary Miss Nelly. Suddenly, Marisol and her father interrupted the show to gift Americans with a flamenco dance. The unexpected emergence of the couple in the bullfighting arena allowed to portray the character of Miss Nelly as a ridiculous foreign figure when exclaimed: "Oh! They are going out to fight with music!" (Palacios \& Sherman, 1965, 0:28:15). Simultaneously, the episode represented a certain attitude of fascination and idolatry towards the foreign. As long as Mister Morrison symbolized a huge purchasing power the natives did not have but wanted to achieve, the song featured by Marisol can be read as a vision of the Americans as an yearning model:

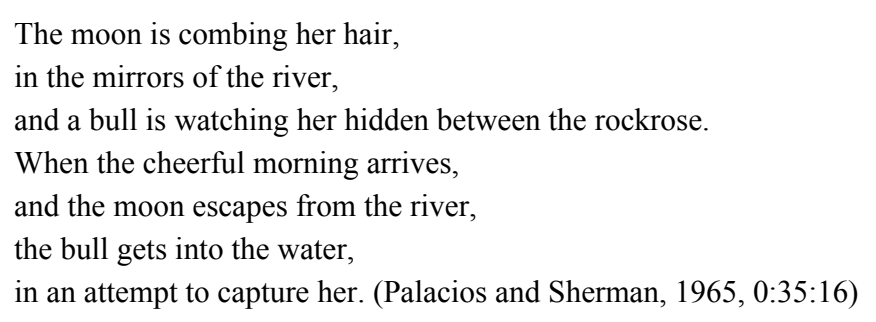

The song of the bull and the moon worked here as a metaphor that could be translated as a country - bull/Spaniards - that aspired to conquer the stars, the firmament-moon/Americans. This idea appeared as ubiquitous in the cinema of the decade and, given that foreigners were mostly characterized as females, it was attached to relevant gender meanings.

Those movies contextualized in tourist environments tended to focus their narratives on the relationship of native men with female visitors. In this sense, the hegemonic narrative of tourism seems to be made from a heterosexual male view. So it was the tourism narrative cinema: screened by and for straight men, offering 
them the pleasure of enjoying a torrent of sexually liberated female visitors who provoke a mixed sense of fear and desire. In fact, on the screens, the tourist group was primarily represented as an attractive and ardent female lovers, able to arouse fascination and desire through native male characters (Donapetry, 2006, p. 132). This kind of representation had to do with a back and forth dialogue between film and the social context. The promotion of coastal towns and islands, the sun and beaches, invited greater exposure of the bodies which, in the case of women, was accompanied by—sexual—accessibility to these bodies. The popular Spanish writer Juan Eslava Galán recalls the admiration aroused among Spanish men by the arrival of women who, unlike the Spanish, were viewed as more accessible and sexually liberated:

Wherever they came from, female visitors, dressed with beautiful bikinis and often blond, were considered Swedish - la sueca - At the same time, Spanish men, who were sexually repressed and weary of too many pray, were eager for catting-up. It was widely thought that flirting with foreign girls was much more easier than with Spanish girls. Besides, the foreign girls were prettier and more appetizing than the natives. (Eslava Galan, 2006, 0:39:20)

From early on, films projected an image of female tourists that fitted perfectly with the description given by Juan Eslava Galán. One of the first films that stuck in the minds of many Spaniards as an evidence of dictatorship moral flexibility and openness was Bahia de Palma (Juan Bosch, 1962). The film, which told the romantic story of a Spanish cavalier and a female tourist, was the first-in the Franco period-to show a woman wearing a two-piece bikini (Gubern, 1981, p. 191). The fact that the garment was worn by Elke Sommer, a German actress, reinforced the idea that that foreign women were less judgemental than Spanish. Linked to the imaginary of those foreign figures and their attitudes, coastal places were viewed by the regime as a real threat. Female visitors customs produced anxiety to the most conservative minds due to the mimicry desire they could provoke, especially among female natives. This imitation risk could compromise the authenticity of the country. And, what was considered far more dangerous, it could open a space to sexual permissiveness, unleashing intolerable sexual behaviours. As it was published in the $A B C$ newspaper referring to Ibiza, tourism was a "double edged sword", and the arrival of foreigners "spoils, intoxicates and adulterates the island, with imported exotic customs". The article continued:

Ibiza's idiosyncrasy, the traditional hospitality of the people of Ibiza, including their elegance, is not enough to alleviate the painful (...) of frivolity and exoticism that are prevalent in Ibiza, a land that once was steeped in secular traditions and now sacrificed to modern times, as her older sister, Mallorca. (Vidal Isern, 1963, p. 26).

Similarly, the intellectual Federico Sáinz Robles pointed out that "more hiding or more hypocritically, bad life is being major characteristic act in today's Spain". From the writer's eyes, citizenship disregarded the requirements and recommendations of pastoral, prelates, and government circulars on the proper sexual behaviour. As a result, he lamented that in Spanish beaches continue "triumphing nudism", the "imported obsessive new dances and the shamelessness" (Sáinz Robles, 1960, pp. 329-330). The possibility of Spanish women imitating foreign behaviourwas seen as a particularly dangerous effect of tourism. And, some way, popular cinema narratives of the sixties bring a solution to this fear and anxieties.

Tourism discourse reinforced - and gave renewed meanings to - the already present idea according to which women were divided in two totally opposite bodies: those sexually liberated - represented by foreigns - and those destined to be wife's - embodied by natives. In contrast to the unprejudiced and permissive foreign women, the soul of the Spanish woman seemed to be unable to offer his body without being in love forever. The iconic figure of Marisol appeared as a paradigm of the sixties national femininity. Marisol 
(Pepa Flores), a mass icon at the time, came to fit perfectly in the formulation of national tourism identity. She excellently embodied the mix of features that the tourism discourse of those days was evoking. The physical aspect of the girl and her genuine personality represented the combination that the Spain is different slogan was seeking: a young and hospitable Spain, clear as its sea and sun, and respectful of the past and the national essence (Evans, 2004, pp. 129-151; Pavlovic, 2011, pp. 124-135; Pavlovic, Perriam, \& Triana-Toribio, 2003, pp. 319-342). It could be said that she appeared as a metaphor of the modern country that welcomed the visitors. The dangerous gender meaning this representation involved - a female national body offered to the public/foreign pleasure - was solved thanks to a desexualized body of the actress ${ }^{6}$.

On her adolescence, Marisol appeared on screen as the ideal Spanish women. Consequently, the characters she embodied were constructed in opposition to foreign women. The film roles she played worked in a way to maintain the traditional sexual order trying to avoid the desire for mimicry Spanish women could feel in their contact with tourists. An example of this idea was offered by the film Búsqueme a esa chica which told the love story of Marisol and Tony. One of the episodes on the movie set out, explicitly, the idea of Spanish femininity uniqueness. It happened when Tony and his brother Mario were singing for foreign tourists and, in the precise moment the lyrics went "I'm looking for someone that is different, like you are, someone who wants to share life to death" the camera directed its gaze to Marisol. The direction of the camera suggested that the song message was addressed to her $(0: 13: 23)$. According to the plot main message, it was the loyalty and faith in marriage what made Marisol—and the Spanish femininity she embodied — exceptional.

There were mainly two connected narrative structures that tried to discourage Spanish women from imitating foreign sexual behaviour. On one hand was that portraying the anti-stereotype that was the representation of tourist women as the sinful Eve. The other way to aim that goal was through "men back home" happy endings. In fact, most movies ended their narratives by native men choosing a native as a wife. In this sense, the claim to reaffirm the traditional values didn't place any veto to the permissiveness with male sexuality. That was the case of Búsqueme a esa chica. The love declaration made by Tony did not involve any waiver of his previous amorous adventures. As he declares in the song that closed the narrative, the young attractive boy "had the look of other eyes" and "the touch of other lips". But, like other male characters of the period, the conclusion of the story came along, as he confessed, with the ending of his adventures:

I searched new horizons

I searched the sound of other voices.

But finally, I woke up and I love only you. (Palacios and Sherman, 1965, 1:34:00-end)

According to this kind of narrative, the period of life in which Spanish men enjoyed sexual freedom ended, in theory at least, to consummate the marriage with a woman who, responding to the ideal, was taught to be chaste. One might even have thought that the representation of foreign as sexual permissiveness was a way to satisfy the male sexual impulses in order to safeguard the Spanish women's decency ${ }^{7}$. Vacation spots - projected as recreation, leisure, and enjoyment spaces — were seen as some kind of a mythological space where the dream of sexual contact could become real. Always acid writer Manuel Vázquez Montalbán

\footnotetext{
${ }^{6}$ The youth of Marisol helped in achieving this objective on the earlier movies she played. As the girl was growing up, film directors and producers tried to hide the signs of her women body.

${ }^{7}$ In a sense, it worked - even on the screens - as a renewed form of prostitution which worked similarly on forties and fifties (Guereña, 2003). In the post-war years the prostitution services were a common demand among males and it became their a space of interaction, as it happened during the thirties (Aguado, 2002, p. 201).
} 
described that belief - myth—as it follows:

\begin{abstract}
Mass tourism immediately created their mythology. Swedish within Spaniard men reach, for example. Some pictorial report had insinuated the freedom of the Nordic and Central European customs. From that base, the Spanish gifted themselves with the right to go on a summer safari full of liberal females. As a result, Spain's coastline came to be the main scenery of a portable life and morality, which returns to its place when the autumn came. There it was possible to see a shortish workman together with a long legged Dutch lady, or a pretty office worker with an English teenager. (Vázquez Montalbán, 1998, p. 188)
\end{abstract}

In this sense, the films of the early seventies raised the need for certain condescension by the wives - or girlfriends - with respect to the idylls and sexual freedom of their husbands - or boyfriends - in order to safeguard the traditional married life (Gubern, 1995, p. 333). At the time, the foreign liberated woman appeared ready to satisfy the sexual needs of the Spanish men, in contrast to the repressed but decent Spanish woman. Hence, the changes in the context, the prominence achieved by sexuality in film narratives, the profusion of stories through which the previously repressed fantasies were screened, did not represent a break with the ideal of up to then prevailing femininity. The absolutely incompatible images of sinful Eve and maternal Maria were still strongly alive. The main difference here with the post-war period was that while then Eve was portrayed through a prostitute body, now the temptation of sin was placed in a foreign body. In our view, this representation main goal was, above all, to kept the integrity of the Spanish woman safeguarded. This role given to the Spanish women, a national female body where sexual pleasure had no place, was part of a sexual nationalism that proclaimed the moral superiority of the national against the foreign.

Obviously, the myth of the romantic summer affair between the macho iberico-Iberian male - and the tourist — a male fantasy that found in these films an encouraging cultural expression — had consequences in the way to understanding the desirable masculinity. The sixties film production focused, mainly, on portraying an image of the Spanish masculinity that, as the country, possessed an innate attractiveness, which the visitor could not resist. Even if it was a way of emphasizing the idea of the foreign female body as a sexually accessible one, it also built a renewed masculine prototype.

\title{
Representation of the Iberian Male or Reinventing the War Virility
}

The sixties tourism stories built a patriotic masculinity linked to sexual conquest of foreign women. The figure of the macho ibérico, protagonist of these films, came to portrait an archetypal idea of the Spanish man whose sexual - heterosexual - potential seemed to prevail over any other dimension of their identity. It was a reinvention of francoism previous years war virility. The post-war idealistic masculinity was defined, among other things, through their ability to control impulses by channelling them through military action. In those years, the trenches, the war, and military values, appeared as the paradigmatic field in which the hegemonic masculinity was defined (Aresti, 2014, pp. 147-177; Vincent, 2006, pp. 135-151; Bunk, 2007, pp. 88-119). In the new developmental context of openness, tourist boom and, as government claimed "XXV Years of Peace", the male prototype prove their manhood through its ability to conquer Swedish, German, or French using his gallantry and his attraction skills. The conquistador, chivalrous and gallant male, appeared on the screens as the epitome of national masculinity.

Popular culture was, in fact, one of the main channels for the broadcasting the myth of the affairs of the macho ibérico and a foreign. One of the early first episodes of the film Búsqueme a esa chica reproduced the romantic myth through a song about a passionate and ardent "very typical Spanish Romance" of a German 
woman and a bullfighter. Performed by Marisol at the precise moment of the arrival of a group of tourist, it worked as a welcome song that promises a sexual affair. Considering the response of one of the spectators, who enthusiastically exclaimed "Oh! Spain Wonderful! Torero!" the sexually active "torero" type, responded to what tourists expected to find in Spain (Palacios \& Sherman, 1965, 0:03:30-0:05:59) ${ }^{8}$. A similar love story was the main storyline one of the big blockbusters of the decade entitled Un beso en el puerto (Ramón Torrado, 1966). Here, it was Manolo Escobar, one of the most popular and acclaimed figures in popular culture of the sixties, who embodied the figure of the macho ibérico in the conquest of a foreign woman". Torrado's film was about the entanglements and comic situations that resulted from the implementation of a "seduction trick". The women conquering main character, who on several times ended in Benidorm prison accused of seducing tourists, was Manolo Espinar. Having taken a few days of relaxation and, guided by his friend Jaime, the hero tried out some seduction tactics. The public and Manolo were explained about the simple procedures through Jaime:

Each boat arrives to the port with a beautiful woman. I approach them with a kiss and a huge (...) I don't give them even time to react. Immediately I say: "Dorothy! What a joy!” (...) The confusion amused her. She explains that she is not called Dorothy. She laughs, I laugh... and the rest is a left hand matter. (Torrado, 1966, 0:12:58-0:13:48)

Encouraged by his friend and visibly drunk, Manolo tried the joke with "the first cute girl who walks through the door" (Torrado, 1966, p. 0:17:18). This first attempt culminated in an absolute failure. However, Manolo didn't give up and, some minutes later, he retried the attack. The very different context that surrounded his second chance defined his success. This time Manolo appeared sober and dressed in a navy captain uniform. He also crossed himself before going to address a woman calling her Dorothy. This episode is symbolically significant as it seems to reproduce the rebels' war renewed values, which were the military discipline and high spirituality. In the sixties, the Spanish hegemonic way of being an exemplary man followed a grammar of war and conquest that worked as an effective metaphor for an active, strong, and determined masculinity in their conquest of those attractive foreign bodies (Pavlovic, 2003, p. 82; Crumbaugh, 2002, pp. 261-276). The contrast between the two episodes, the first unsuccessful and the second successful, suggested that for a victorious conquest of the female body, a combination of faith and military values were, as in war, mandatory. In fact, that second time, having commending his soul to God, uniformed and with senses alert, Manolo reached his goal. He conquered the woman, whose name was coincidentally Dorothy.

The popular cinema coincided on screening a condescending narrative progress regarding male promiscuity. Moreover, it was a kind of praise about the womanizer. As it could be watched in one of the episodes of Un beso en el puerto, when Manolo stayed in jail accused of seducing tourist, he made a defence of the gallantry culture that defined the typical Spanish masculinity:

For a kiss I gave to a lady that I did not know (...) I am in this prison. If my bones had known, I would have filled her till the heart with kisses (...) I will never turn away from the port. I will flatter to Spanish and foreign, and as long as they let me, I will also kiss them. Because we-Spanish men—are that gallant. (Torrado, 1966, 0:34:00-0:35:30)

\footnotetext{
${ }^{8}$ The sung story, and thus the male body, became part of the dictatorship "package tour". It could be considered that low prices and quality of the Spanish beaches were not the only attractions of the country and we should not dismiss the possibility that Spain may be considered also a sex tourism destination (De Miguel, 1976, p. 141; Cáceres, 2008, pp. 20-23). Thus, the touristic macho iberico's narratives did not offer an unequivocal interpretation and had, in fact, a problematic dimensions.

9 The fact that actor had married a German woman in 1959 appeared to provide more realism to the screened story and to the main character. As noted by the actor himself in relation to his romance with Ana Marx, their love history "seemed to be straight out of a movie plot of the time: the tourist who falls in love with a folk singer" (Barba, 2009, p. 50).
} 
If gallantry and seductive attitude were part of Spanish male identity, Manolo could only assume his fate "as the brave men" (Torrado, 1966, p. 0:33:10). The sixties popular cinema insisted in that definition of masculinity, according to which the Spanish man was not able to restrain himself in the presence of a female body. The constantly reproduction of this statement leads us to think about the possibility to consider the figure/message of the macho ibérico working against what the most traditional social sectors of the time perceived as ambiguous masculinity. Francoism sixties male prototype responded to a reaffirmation of a strong heterosexual identity in opposition to the growing ambiguity among young men and likened to modern fashions. The popular yeyé ${ }^{10}$ aesthetic, attitudes, lifestyle, and culture that accompanied the openness discourse represented the change versus the continuity and traditional values. Manolo Escobars' appearance and character, both on the screen and out of it, gave no room for masculine either patriotic ambiguity. Popularly known as “the voice of Spain" (Crumbaugh, 2002, pp. 261-276; López, 2011, p. 273), it wasn't only his music, but also his appearance - dressed unadorned, short hair combed - responded to the traditional aspect of sober and austere Spanish aesthetics. Hence, the paradigmatic male virility that was constantly embodied by Manolo Escobar responded to the idea of "men, not sissies", claimed by the admiral Luis Carrero Blanco. According to him, the authentic national masculinity was that defended an spirit of "manhood, patriotism, honour, decency" (Prego, 1995, p. 18; Mira, 2007, pp. 365-370). Manolo Escobar replied, body and soul, to that view of the national masculinity full of authenticity, and so uncontaminated by disturbing modernism. In this sense, Spanish manhood, defined by his sexual instinct and virile potential, was fighting a new crusade against foreign new trends that were affecting traditional gender identities ${ }^{11}$. As stated by the protagonist of Un beso en el puerto, the latin lover was not "a thief or something like it" but a "Spanish gentleman" (Torrado, p. 0:37:50, 1:09:00) whose main enemy, we add, was the male ambiguity.

Even the praise about the womanizer showed by Un beso en el puerto, it was not the intention of the movie to propose the idea of an eternal bachelor seducer as an ideal. In line with the sexual codes still in force, the outcome of the film proposed the idea that the amorous adventures of the macho iberico concluded with the arrival of marriage ${ }^{12}$. Thus, the happy ending of the movie came along with the wedding between Manolo and Dorothy. The story acquitted even Jaime, who throughout the story proved to be much more promiscuous than the protagonist. Lulu, a French woman whose father tried, throughout the entire film, to find the father of his grandson, identified Jaime as her seducer and the responsible of her pregnancy. Although he remained rejecting his paternity during the main time of the plot, at the end he recognized himself as "responsible for what had happened" assuming his male duty as father of the child (Torrado, 1966, p. 1:18:18). That marriage happy ending was the way in which the narrative redeemed the inventor of the "seduction trick" while discarding the image of the protagonist as an irresponsible seducer. As the majority popular film production did, Un beso en el puerto proposed a condescending attitude through heterosexual male sexual adventures, ultimately consolidating the traditional marriage model. So, even defined by his boundless sexual impulses, male prototype of the sixties

\footnotetext{
10 Anglicism referred to modern music.

11 Far from the suspicion of effeminacy suffered by the seducer figure of the Don Juan in the first third of the XX century the seductive man and conqueror of the sixties was the epitome of virile masculinity. That past male figure was strongly battled by the scientists of the time, particularly by the liberal ones. It is significant to see that the main character of Un beso en el puerto appeared as an opposing male model —neglecting his work duties e.g. - of that responsible, rational and hard worker manhood that was enhanced from the liberal and intellectual circles in order to "dethrone" the Don Juan Figure (Aresti, 2001, pp. 115-161).

12 That way thee cinematography of the seventies tended to consolidate the idea that male sexual pleasure only found its place outside the marriage framework.
} 
was also constructed in respond to the marital destiny.

\section{Conclusions}

The values and behaviours that define the socially acceptable bodies are always subjected to historical contingency. However, even if identities are in continuous transformation processes, there are moments particularly perceived as in change. That was the case of the sixties Spain. Tourism industry and discourse became a useful modern mechanism through which articulate a renewed patriotic concept and a collective acceptance of the economic developmental discourse. But, in that transformation period, it was also helpful to avoid deeper or uncontrolled changes. The approach to the meanings of Spain is different slogan, helps us to see how, among with it's aim to build an attractive image to the outsiders, it also created a renewed image of Spain to itself.

In these pages we have highlighted the ability that the tourist imaginary had in the construction of gender identities. Tourism films reproduced and constructed a renewed form of manhood, the virile macho iberico, defined by his strong sexual impulses. At the same time, portraying the foreign as immoral liberated females, this kind of cinema reinforces the Spanish virginal womanhood. Both figures, Spanish men and women, were called to the marriage as an ideal. But being also a time when certain sexual permissiveness-limited to heterosexual men - started, native women were asked to be magnanimous with their partners. That way, while portraying a certain new era, characterized by economical development and a moderate modernity, the double standard regarding gender behaviours became deepen. We can conclude that, the battlefield of the prototypical masculinity and femininity passed from the war trenches — and rear- to the coastal arena, where amorous matters were plotted aiming their messages to native men and women.

\section{References}

Afinogenova, E., \& Martí-Olivella, J. (2008). Spainis (still) different: Tourism and discourse in Spanish identity. Lanaham: Lexington Books.

Aguado, A. (2002). La experiencia republicana. Entre la cultura del reformismo político y las culturas obreras (The Republican experience: Between political reforms' culture and working cultures). In A. Aguado, \& M. D. Ramos (Eds.), La modernización de España (1917-1939). Cultura y vida cotidiana (Spanish modernization (1917-1939): Culture and everyday life) (pp. 153-222). Madrid: Síntesis.

Aresti, N. (2001). Médicos, donjuanes y mujeres modernas: los ideales de feminidad y masculinidad en el primer tercio del siglo XX (Doctors, Don Juan's and modern women: Femininity and masculinity ideals in the firth three decades of the XXth Century). Bilbao: EHU/UPV.

Aresti, N. (2010). Masculinidades en tela de juicio. Hombres y género en el primer tercio del siglo XX (Masculinity under judgement: Men and gender during the first three decades of XX Century). Cátedra, Madrid.

Aresti, N. (2014). The battle to define spanish manhood. In A. Morcillo (Ed.), Memory and Cultural History of the Spanish Civil War: Realms of Oblivion (pp. 147-177). Leiden and Boston: Brill.

Barba, D. (2009): 100 españoles y el sexo (100 spaniards and sex). Barcelona: Random House Mondadori.

Barbadillo, P. (1997). Extranjería, racismo y xenofobia en la España contemporánea. La evolución de los setenta a los 90 (Foreigness, racism and xenophobia in Contemporary Spain: From 70s to 90s). CIS, Siglo XXI, Madrid.

Bennett, T. (1986). Popular culture and social relations. Milton Keynes: Open University Press.

Biescas, J. A., \& Tuñón de Lara, M. (1990). España bajo la dictadura franquista (1939-1975). Barcelona: Labor.

Bonami, F. (2005). Universal experience: Art, life, and the tourist's eye. Chicago: Museum of Contemporary Art.

Bonnel, V. E., \& Hunt, L. (1996). Beyondthe cultural turn: New directions in the study of society and culture. Berkeley, Los Ángeles: University of California Press.

Bosch, J. (1962). Bay of Palma (Bahía de Palma).

Bunk, B. D. (2007). Grandsons of the Cid: Masculinity, sexual violence, and the destruction of the family. In Ghosts of Passion: Martyrdom, Gender and the Origins of the Spanish Civil War (pp. 88-119). Durham and Londres: Duke University Press. 
Butler, J. (1993). Bodies that matter: On the discursiv elimits of "sex". New York: Routledge.

Butler, J. (1999). Gender trouble: Feminism and the subversion of identity. New York: Routledge.

Butler, J. (2004). Undoing gender. New York: Routledge.

Cáceres, J. (2008). El destape del macho ibérico: masculinidades disidentes en la comedia sexy (celt)ibérica (Macho ibericos' nudity. Dissident masculinities in the (celt)iberic sexy comedy). UMI, Washington.

Cannel, D. M. (1976). Thetourist: A new theory of theleisureclass. New York: Schocken Books.

Cenarro, A. (1998). Muerte y subordinación en la España franquista: El imperio de la violencia como base del "Nuevo Estado" (Death and subordination in fransoism Spain: Violence as the basis of the "New State"). Historia Social, 30, 5-22.

Crumbaugh, J. (2002). "Spainis different": Touring Late-Francoist Cinema with Manolo Escobar. Hispanic Research Journal: Iberian and Latin American Studies, 3(3), 261-276.

Crumbaugh, J. (2007). El turismo como arte de gobernar: Los felices sesenta del franquismo (Tourism as a government art: fransoism happy sixites). In A. Del Rey Reguillo (Ed.), Cine, imaginario y turismo. Estrategias de seducción (Cinema, imaginery and tourism: Seduction strategy) (pp. 157-158), Tirant Lo Blanch, Valencia.

Crumbaugh, J. (2009). Prosperity and Freedom under Franco: The Grand Invention of Tourism. In Destination Dicatorship: The Spectacle of Spain's Tourist Boom and the Reinvention of Difference (pp. 15-39). Albany: State Univestity of New York Press.

De Miguel, A. (1976). 40 millones de españoles 40 años después (40 million Spaniards 40 years later). Grijalbo, Barcelona.

Díaz Freire, J. J. (2003): Cuerpos en conflicto. La construcción de la identidad y la diferencia en el País Vasco a finales del siglo XIX (Bodyes in conclict: The construction of identity and difference in the last years of XIXth Century Basque Country). In M. Nash, \& D. Marre (Eds.), El desafio de la diferencia: representaciones culturales e identidades de género, raza y clase (The challenge of the difference: Cultural representations and gender, race and class differences) (pp. 62-70). UPV/EHU, Bilbao.

Díaz Freire, J. J. (2007). Cuerpo a cuerpo con el giro lingüístico (Hand to hand with the linguistic turn). Arenal, 14(1), 5-29.

Donapetry, M. (2006). Imagi/nación: La feminización de la nación en el cine español y latinoamericano (Imagy/nation: The femininity of the nation in the Spanish and Latin American cinema). Fundamentos, Madrid.

Eslava Galán, J. (2006). Turismo, Información y Censura (Tourism, information and censorship). In J. Gil Pecharromán (dir.), Asi fue la España de Franco (That's how it went Franco's Spain), Arlanza, Madrid: Chapter 8.

ESPAÑA (MIT). (1953). Plan Nacional de Turismo (Tourism National Plan). Madrid: Suc. de Rivadeneyra.

Evans, P. W. (2004). Marisol: The Spanish cinderella. In A. Lázaro Reboll, \& A. Willis (Eds.), Spanish Popular Cinema (pp. 129-151). Manchester, New York: Manchester UniversityPress.

Faulkner, S. (2006). A cinema of contradiction: Spanish film in the 1960s. Edinburg: Edinburgh University Press.

Foucault, M. (1977). Historia de la sexualidad. La voluntad de saber (History of sexuality: The will to knowledge). Siglo XXI, Madrid.

Foucault, M. (2002). Vigilar y castigar: nacimiento de la prisión (Discipline and punishment: The birth of the prison). Siglo XXI, México, Argentina.

Fraga Iribarne, M. (1965). Horizonte español (Spanish Horizon). Madrid: Editora Nacional.

Gubern, R. (1981). La censura: función politica y ordenamiento jurídico bajo el franquismo (1936-1975) (Censorship: Political function and legislation under francoism (1936-1975)). Península, Barcelona.

Gubern, R. (1995). Historia del cineespañol (History of Spanish cinema). Cátedra, Madrid.

Guereña, J. L. (2003). Prostitution in Contemporary Spain (La prostitución en la España contemporánea). Marcial Pons, Madrid.

Kirshenblatt-Gimblett, B. (1998). Destination culture: Tourism, museums and heritage. Berkeley, Los Ángeles, London: University of California Press.

Labanyi, J. (2010). Doing things: Emotions, affect and materiality. Journal of Spanish Cultural Studies, 11(3-4), 223-233.

Longhurst, A. (2000). Culture and development: The impact of 1960s "desarrollismo". In B. Jordan, \& R. Morgan-Tamosunas (Eds.), Contemporary Spanish Cultural Studies (pp. 17-28). London: Arnold.

López, P. (2011). People from Alicant in the Cinema (Alicantinos en el cine). Alicante: Editorial Club Universitario.

Lucía, L. (1960). A ray of light (Un rayo de luz).

Martín, A. (2007a). Familia, turismo y garrote vil: El verdugo de Luis García Berlanga (Family, tourism and garotte: Luis García Berlanga's The executioner). In J. Herrera, \& C. Martínez-Carazo (Eds.), Hispanismo y Cine (Hispanicism and Cinema) (pp. 269-292), Madrid: Frankfurt-Vervuert-Iberoamericana. 
Martín, A. (2007b). Subdesarrollo de cinco estrellas: La guía identitaria del desarrollismo (Five stars under development: Desarrollismos' indetity guide). In A. Del Rey Reguillo (Ed.), Cine, imaginario y turismo. Estrategias de seducción (Cinema, imaginery and tourism. Seductionstrategy) (pp. 179-207). Tirant Lo Blanch, Valencia.

Mira, A. (2007). De Sodoma a Chueca. Una historia cultural de la homosexualidad en españa en el siglo XX (From Sodoma to Chueca: A cultural history of Spanish homosexuality in the XXth Century). Egales, Barcelona and Madrid.

Molinero, C., \& Ysás, P. (1999). Modernización económica e inmovilismo político (1959-1975) (Economical modernization and political inmovilism (959-1975)). In J. A. Martínez (coord.), Historia de España. Siglo XX (1939-1996) (Spanish History, XX Century (1939-1996)) (pp. 129-242). Cátedra, Madrid.

Molinero, C., \& Ysás, P. (2008). La anatomía del franquismo. De la supervivencia a la agonía, 1945-1977 (Francosimanatomy: From survival to agony, 1945-1977). Crítica, Barcelona.

Morcillo, A. (2008). True Catholic womanhood: Gender ideology in Franco's Spain. Illinois: Northern Illinois University Press.

Morcillo, A. (2010). The seduction of modern Spain: The female body and the Francoist body politic. Lewisburg: Bucknell University Press.

Pack, S. D. (2009). La invasión pacífica: Los turistas y la España de Franco (Peaceful invasion: Tourists and Franco's Spain). Turner, Madrid.

Palacios, F., \& Sherman, G. (1965). Look for that girl (Búsqueme a esa chica).

Pavlovic, T. (2003). Despotic bodies and transgressive bodies: Spanish culture from Francisco Franco to Jesús Franco. Albany-New York: State University of New York Press.

Pavlovic, T. (2004). España cambia de piel: The mobile nation (1954-1964). Journal of Spanish Cultural Studies, 5(2), $213-226$.

Pavlovic, T. (2011). The movile nation: España cambia de piel (1954-1964). Bristol: Intellect.

Pavlovic, T., Perriam, C., \& Triana-Toribio, N. (2003). Stars, modernity, and celebrity culturte. In J. Labanyi, \& T. Pavlovic (Eds.), A companion to Spanish cinema (pp. 319-342). Oxford and Chichester: Blackwell, Malden.

Prego, V. (1995). Asi se hizo la Transición (That' show the transition was). Plaza y Janés, Barcelona.

Sáinz de Robles, F. C. (1960). Ayer y hoy: la evolución de la sociedad española en cien años (Yesterday and today: Spanish society evolution in a hundred of years). Aguilar, Madrid.

Torrado, R. (1966). A kiss in the port (Un beso en el puerto).

Vázquez Montalbán, M. (1998). Crónica sentimental de España (Spanish sensitive report). Grijalbo Mondadori, Barcelona.

Vázquez, F., \& Cleminson, R. (2012). Los hermafroditas. Medicina e identidad sexual en España (1850-1960) (The hermaphrodite's: Medicine and sexual identity in Spain (1850-1960)). Comares, Granada.

Vidal Isern, J. (1963). Baleares. La tradición de Ibiza, en peligro (Baleares, Ibiza's tradition in danger). $A B C$.

Vincent, M. (2006). La reafirmación de la masculinidad en la cruzada franquista. Cuadernos de Historia Contemporánea, 28, $135-151$. 